\title{
EXPLORING THE IMPACT OF DESTINATION PERSONALITY ON FOREIGN TOURIST'S REVISIT INTENTION: THE CASE OF HANOI AND QUANGNING, VIETNAM
}

\author{
Trinh Thi Thu Huong* and Tran Hai Ly \\ Foreign Trade University, Vietnam
}

\begin{abstract}
Factors influencing tourist behavior have been focal point in marketing tourism research for decades. Tourism plays an important role in the economic development of Vietnam. The objective of my research was to investigate the destination personality of Vietnam and to examine the relationship between destination personality and foreign tourist's revisit intentions. Both qualitative and quantitative method are used in this study. A survey with convenience sample of 401 speaking English visitors to Hanoi and Quangning, Vietnam was conducted. The findings of the study indicate that tourists ascribe personality characteristics to destinations and the destination personality of Vietnam includes the dimensions: excitement, sincerity, competence, sophistication, ruggedness, Vietnamese personality with peaceful and messiness. These dimensions have a positive influence on tourist's intention to return and intention to recommend. The study concludes that destination personality is a significant factor on the impact of destination personality on foreign tourist's behavioral intentions. The research also provided managerial implications for destination marketers based on the results. The study offers multiple theoretical and practical implications for both academicians and practitioners.
\end{abstract}

Keywords: destination personality, tourist, revisit intention, return, recommend, Vietnam

\section{Introduction}

Vietnam's economic growth prospects are strongly driven by its travel and tourism sector. Tourism plays major role in Vietnam's socio-economic development. The tourism sector has been a major factor in job creation, economic development and poverty alleviation in Vietnam. According the data source from Ministry of Culture, Sport \& Tourism of Vietnam, tourist arrivals in Vietnam have continued to rise in recent years. In 2015, Vietnam received 7.943 million international tourists; in 2016 the number was 10.012 million, increase 26\%. In 2017, Vietnam received 12.922 million tourists. This was a $29.1 \%$ increase from 2016. Vietnam's rapid tourism growth clearly shows the country's worth visiting. However, the return visitor's rate is low. $70 \%$ of tourists do not return to Vietnam.

As the market of tourism destinations has increasingly become more competitive, the revisit intention topic has progressively become prominent to emphasize on. Due to this highly competitive environment, it has become imperative for destinations both to remain differentiated and to be able to promote their unique characteristics. The increase in disposable income, media that are more efficient, an increase in leisure time and more efficient transportation network servicing competing destinations all add to the choices on offer to travelers (Echtner \& Ritchie, 1991). To achieve this, tourism marketers need to position destinations differently in the minds of travelers. A critical component required for this positioning process is the creation of a unique personality for the destination (Sirgy, 1982). Enkinci and Hosany (2006) suggest that destination personality can be used as a viable 
metaphor for building destination brands, understanding visitor's perceptions of destinations, and crafting a unique identity for tourism places. Thus, the country should focus on developing marketing campaigns emphasizing the distinctive personality of their destinations. A unique and distinctive brand personality helps in brand differentiation (Aaker, 1996), increase brand equity (Keller, 1993), enhances brand equity (Keller, 1993), enhances brand preference and usage (Aaker, 1999; Sirgy, 1982), builds strong attachment between brands and consumers (Landon, 1974), and evokes emotional links between brands and consumers. It thus leads to greater trust and loyalty (Fournier, 1998). The tourism literature review reveals that the study of destination personality (DP) is still in a nascent stage. Essentially, understanding the factors influencing the revisit intention of international visitors suggestively allows destination tourism managers or authorities to fundamentally know better on how to develop effective tourism marketing and management strategies and build up travel motivation to attract visitors. Regarding the economic perspective, the study on repeat visitation is substantially crucial for tourism businesses to operate effectively and efficiently. Indeed, attracting the previous visitors is more cost-effective than gaining the new ones as the promotional costs in attracting the repeat visitors are certainly less than the first time visitors. Business tends to heavily rely on loyal customers which act as a key role in driving the profitability.

Researches on tourism reveal that destinations with favourable personality are more likely to influence tourism behavior (Chen \& Phou, 2013; Enkinci \& Hosany, 2006; Usakli \& Baloglu, 2011). Hence, destination personality has surfaced as an effective tool for destination branding. Destination personality may act as an important tool for building destination brands and recognizing visitors' perceptions of destinations (Enkinci \& Hosany, 2006). The significance of destination personality in terms of understanding visitor perceptions and behavior emphasizes the necessity of developing methodologies to measure this concept comprehensively and precisely. Furthermore, the study examines the evaluation of the visitors about destination personality during their visit in Hanoi and Quangning, Vietnam. More importantly, the study provides recommendation to tourism business and tourism department in Vietnam to implement strategies and actions that enhance the quality of their product and services sustainably attract the loyal visitors.

\section{Literature Review}

\section{Brand personality}

The literature on consumer behavior reveals that the idea of branding has been thoroughly researched and followed in the general marketing field. However, the application of branding to tourism destination is recent development (Ekinci \& Hosany, 2006). A strong brand helps in differentiating a product from its competitors (Keller,1993). The researchers and practitioners of destination branding consider destination as a product and assume that it can be branded just as products. However, building destination brands is a more complex and different process than building brands for unidimensional products and services (Hankinson, 2001). The process of destination includes capturing the different elements of the destination in the brand and communicating those to potential and current consumers through different components of the brand such as bran personality.

Brand personality can be defined as "the set of human characteristics associated with a brand" (Aaker, 1997). Although brands are inanimate objects, consumers often view them as having human characteristics (Aaker, 1997). These characteristics could be traits, for instance, one may use the following words to describe some popular brands: "cool" for Coca Cola, "masculine" for Marlboro 
(Ekinci \& Hosany, 2006). Understanding brand personality is important because consumer select brands with personality that are acceptable to them (Aaker, 1999). Many researchers have attempted to understand brand personality, but research on brand personality has remained limited due to the lack of both a conceptual framework and a reliable, valid and generalizable scale to measure brand personality (Aaker, 1997), called The Brand Personality Scale (BPS), based on a representative sample and a comprehensive list of personality traits.

Aaker (1997) demonstrates the validity of the brand personality construct. The BPS has five basic dimensions: sincerity, sophistication, ruggedness, excitement, and competence. Since then, numerous researchers have replicated Aaker's (1997) BPS framework using a variety of consumer brands within different product categories and across different settings (Siguaw, Mattila \& Austin, 1999). Based on the above discussions, one can conclude that brand personality is an extension of human personality traits to products/brands. Likewise, researchers have further broadened the scope of personality construct to encapsulate destinations. Hence, destination personality may be described as the set of human characteristics associated with a person visiting a destination.

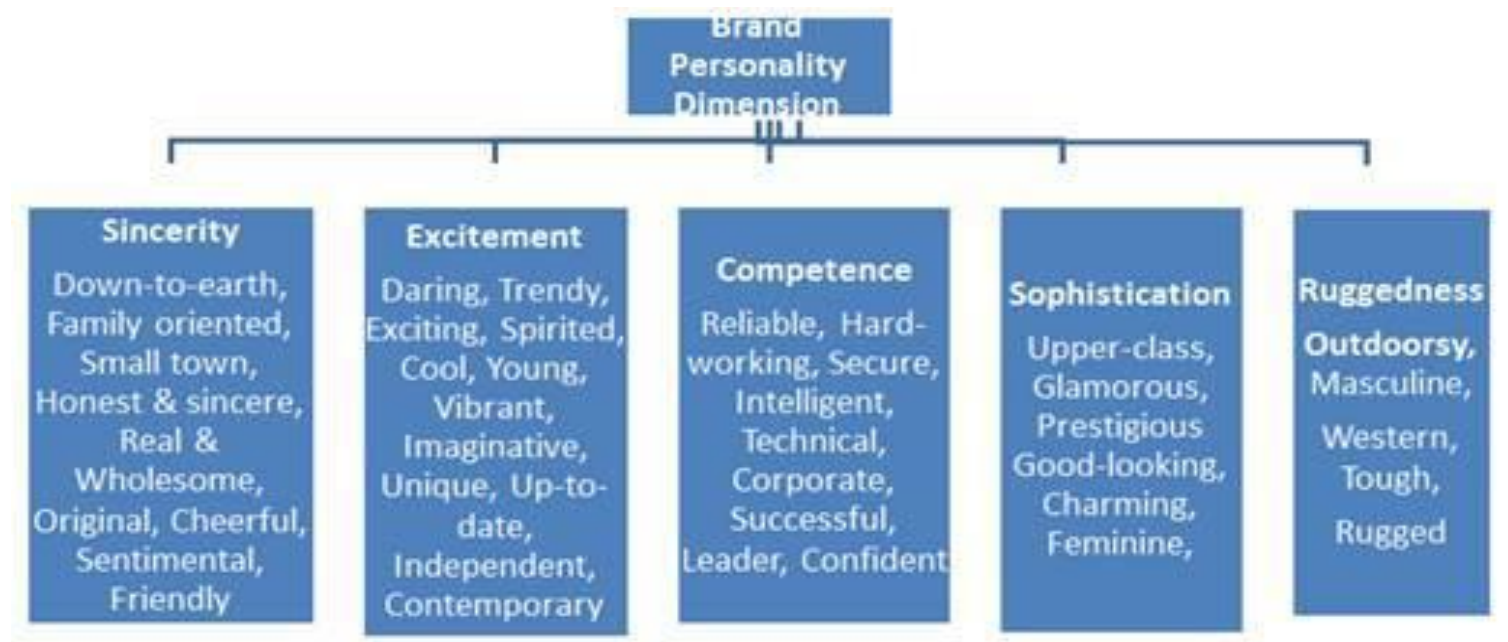

Fig. 1.The brand personality scale (BPS), Aaker, 1997.

\section{Destination personality: the application of brand personality to tourism destinations}

Destination personality refers to brand personality in the context of tourism literature. Ekinci and Hosany (2006) define destination personality as "set of personality traits associated with a destination", adapting Aaker's (1997) brand personality terminology. Although product/brand personality research in the consumer goods domain began in the early 1960s, the investigation and application of brand personality to tourism destinations are relatively new (Ekinci \& Hosany, 2006). A well-established brand personality facilitates differentiation of a brand from that of its competitors (Aaker, 1996). Similarly, a distinctive and attractive destination personality can effectively leverage the perceived image of a destination, and thereby, influence tourist choice behavior (Ekinci \& Hosany, 2006).

Ekinci and Hosany (2006) are the first to examine the applicability and validity of Aaker's (1997) brand personality framework in the context of tourism destinations. The authors found that tourists ascribe personality characteristics to destinations, and hence, the concept of BPS can be applied to 
tourism destinations. They concluded that destination personality consists of three salient dimensions, rather than the original five dimensions. Sincerity and excitement were found to be the two main factors. Conviviality was new and specific to destinations (Ekinci \& Hosany, 2006). Since then, empirical studies on destination personality began to emerge in the tourism literature.

\section{Revisit intention}

Like other products, tourists deliberately go through the process of planning and decision-making in selecting the vacation destination. They enormously spend their time and effort in actively gathering information and thoroughly assessing the alternative destinations before the final decision is being settled (Howard, 1969). Essentially, the destination choice is influentially determined by risk, attractiveness and quality in which the tourists perceive. With its intangible nature and social implications, although the purchase frequency is low, the purchase value is substantially high. According to Howard, the buying decision-making of major behavioral process consists of three stages including pre-decision and decision process, post-purchase evaluation and future decisionmaking.

Consumer loyalty is magnificently vital to a product and service in every industry. It is six times costly to attract new consumers are deemed to have 10 times more value than the price of a single purchase (Jones, 1995). They act as another channel in promoting the product and service through informal recommendation and word of mouth to friends, relatives, and other potential travelers to a destination (Jooyeon Ha, 2009). As a result, this certainly helps the service providers to gain more revenue as well as reduce marketing cost. Yoon and Uysal (2009) proved that both push and pull factors that act as tourist motivation have a vital impact on destination loyalty measured by the likelihood of revisit intention and word-of-mouth recommendation. In fact, the likelihood to recommend a product or service again, and overall satisfaction constitute as effective indicators in evaluating consumer loyalty. Repeat visitation is highly prominent to tourism industry of a destination.

\section{Proposed Model}

It has been argued that a distinctive brand personality has positive effects on brand attitudes (Helgeson \& Suphellen, 2004). More specifically it contributes to the differentiation of a specific brand from those of its competititors (Aaker, 1996), increases brand preference and usage (Sirgy, 1982), results in greater loyalty (Fournier, 1998). Applying the concept of brand personality to tourism destinations, previous studies have investigated the effects of destination personality on tourist's behavioral intentions. For instance, Ekinci and Hosany (2006) have found that one of the dimensions of destination personality has a significant effect on intention to recommend. Ekinci et al.(2007) have found that destination personality has a positive influence both on intention to return and word of mouth. Following these studies, the present study proposed that destination personality will have direct positive influence on tourist's behavioral intentions. Accordingly, the following hypotheses were derived:

Destination personality will have a positive impact on intention to return. 


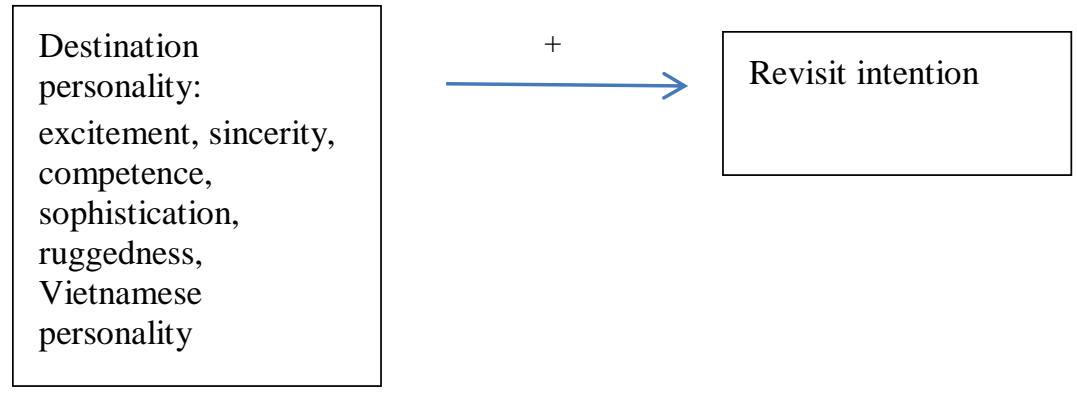

Fig. 2. The hypothesized model

\section{Methodology}

This study applied a survey research design. A self-administered questionnaire was developed based on the literature review, scale development procedure, and interviews with the marketing managers of Tourism companies in Hanoi and Quangninh. Both close and open-ended questions were used in the questionnaire to collect the require quantitative and qualitative data for the study. Hanoi and Quangninh were choosed as two destinations to survey tourists because they are famous destinations in Vietnam.

\section{BPS development for destination}

Although Aaker's (1997) BPS is the most comprehensive instrument for measuring brand personality and is widely used within different product categories and across different cultures, it is not specifically designed for tourism destinations. Hosany et al.(2006) suggest that some items of Aaker's (1997) BPS are redundant in the context of tourism destinations, because they are not suitable to define a tourism destination. Therefore, to ensure that the personality traits used in this study are pertinent to Vietnam, a two-stage scale development procedure was conducted. In the first stage, a free-elicitation task was conducted to identify the uinique traits that describe Vietnam. In the second stage, the 42 personality traits in the BPS were tested for content validity.

\section{Stage 1: unique personality trait generation}

In this stage, to identify the traits unique to Vietnam a free-elicitation task was conducted among a group of 62 tourists visiting Hanoi. Subjects were recruited using a convenience sampling technique on Hanoi trip. Subjects were recruited using a convenience sampling technique, from 5/5/2017 to 5/7/2017. Subjects, (57\% female, $43 \%$ male) from speaking English countries, were asked to think of Vietnam as if it were a person and to write down the personality traits that first came to mind. Fourteen unique traits resulting from this task met this criterion and were added to the pool of personality traits.

Table 1: The unique personality traits for Vietnam destination

\begin{tabular}{|l|l|l|}
\hline No & Resulting traits & Frequencies (\%) \\
\hline 1 & Friendly & 45 \\
\hline 2 & Peaceful & 34 \\
\hline 3 & Charming & 31 \\
\hline 4 & Natural beauty & 30 \\
\hline
\end{tabular}




\begin{tabular}{|l|l|l|}
\hline 5 & lovely & 28 \\
\hline 6 & Easy-going & 27 \\
\hline 7 & Traditional & 27 \\
\hline 8 & Delicious cuisine & 26 \\
\hline 9 & Laid-back & 22 \\
\hline 10 & Kind & 21 \\
\hline 11 & Messy & 21 \\
\hline 12 & Noisy & 20 \\
\hline 13 & Dirty & 18 \\
\hline 14 & Chaotic traffic & 17 \\
\hline
\end{tabular}

\section{Stage 2: the BPS content validity}

A group of 100 visitors was used in the second stage. In this stage, the 42 personality traits in the BPS were tested for content validity (Churchill, 1979). The items were measured using a 5-point Likerttype scale, with anchors ranging from (1) not descriptive all to (5) extremely descriptive, consistent with Aaker's (1997) study. Subjects were asked to rate the degree to which they perceived that each of the 42 personality traits accurately described Vietnam (include 3 trait in Vietnam destination personality). A set of 26 items, split across 5 dimensions, was retained from the BPS and 11 Vietnamese personality trait were yielded for the final study.

\section{The measurement}

Destination personality measurement

The destination personality was captured using personality traits derived from unique personality trait generation stage and mostly, Aaker's(1997)BPS content validity stage. A total of 37 destination personality items was measured on a 5-point Likert type scale ranging from (1) strongly disagree to (5) strongly agree.

\section{Revisit intention measurement}

Based on literature review, revisit intentions consist of intention to return and intention to recommend, that were measured on a 5-point Likert type scale ranging from (1) strongly disagree to (5) strongly agree.

\section{Sample and data collection}

The data were collected from October, 2017 to March, 2018. The surveys were conducted graduate students. The students approached the visitors who were in Hanoi and Quangninh. Out of 500 questionnaires collected, 99 were not usable. Thus, a total of 401 questionnaires were coded for data analysis.

\section{Analysis of data}

The software SPSS 20.0 was used to analyze the data. Data analysis included several stages. First, the data were explored for possible errors in the entries and outliers; and descriptive statistics were 
reported. Next, a factor analysis was performed to identify the underlying personality dimensions of Vietnam.

\section{Results and Discussion}

\section{Demographic profile of the respondents}

There were slightly more female respondents (54\%) than Males (46\%). The age of the respondents ranged from 20 to 29 was higher than other groups. The respondents were $40 \%$ from the Europe, $17 \%$ from North of American, 30\% from Australia. The major portion of the respondents (49\%) belonged to the income group of under $\$ 49000$.

\section{Trip characteristics}

More than half of the respondents (62\%) were first-time visitors to Vietnam. The remaining $22 \%$ had visited Vietnam the second-time, $15 \%$ had visited Vietnam the third-time. Respondents stayed average under 1 month.

\section{Cronbach's Alpha and Exploratory factor analysis (EFA) of destination personality items}

An exploratory factor analysis was performed on the 37 personality items to reduce data and to identify the underlying dimensions. Cronbach's alpha was used to test the reliabilities.

Table 2: Cronbach's Alpha and EFA analysis of Vietnam destination personality item

\begin{tabular}{|l|l|l|l|l|l|l|}
\hline Factors & $\begin{array}{l}\text { Cronbach } \\
\text { 's Alpha } \\
\text { (N of } \\
\text { items) }\end{array}$ & $\begin{array}{l}\text { Minimum } \\
\text { of total } \\
\text { item } \\
\text { corrected } \\
\text { correlation } \\
\text { s }\end{array}$ & $\begin{array}{l}\text { Minimum } \\
\text { of the } \\
\text { factor } \\
\text { loadings }\end{array}$ & KMO & p-value & $\begin{array}{l}\text { TVE } \\
\text { (Total } \\
\text { variance } \\
\text { explaine } \\
\text { d) }\end{array}$ \\
\hline Sincerity & 0.896 & 0.870 & 0.801 & $0 . .826$ & 0.000 & 65.857 \\
\hline Excitement & 0.902 & 0.886 & 0.658 & 0.898 & 0.000 & 54.066 \\
\hline Competence & 0.864 & 0.804 & 0.801 & 0.769 & 0.000 & 71.378 \\
\hline $\begin{array}{l}\text { Sophisticatio } \\
\text { n }\end{array}$ & 0.809 & 0.677 & 0.810 & 0.693 & 0.000 & 72.441 \\
\hline Ruggedness & 0.834 & 0.601 & 0.713 & 0.689 & 0.000 & 75.351 \\
\hline $\begin{array}{l}\text { Vietnam traits } \\
\text { (Peaceful and } \\
\text { Messy) }\end{array}$ & 0.916 & 0.905 & 0.572 & & & 6.000 \\
\hline
\end{tabular}

The EFA analysis showed that the scale Factor all dimensions of destination personality is a unidimensional scale and the data fit to use EFA method, as in the table above. 


\section{Confirmatory factor analysis of destination personality traits}

The study used confirmatory factor analysis (CFA) to assess official data. The result showed that the research model reached overall fit with actual data. Chi-square $=2,551$ is smaller $3, \mathrm{CFI}=0,900$, TLI $=$, IFI $=0,901$ are larger than0,85 and RMSEA $=0,062$ is smaller than 0,08. The factor loading of all items in each construct are larger than 0.5, this indicated the construct achieved the convergent validity and the correlation coefficient of each construct are smaller unity shows that the construct in the model reach the discriminate validity. The composite reliability coefficient is larger 0.6 and average variance extracted (AVE) is larger $30 \%$ which showed that the scale achieved reliability.

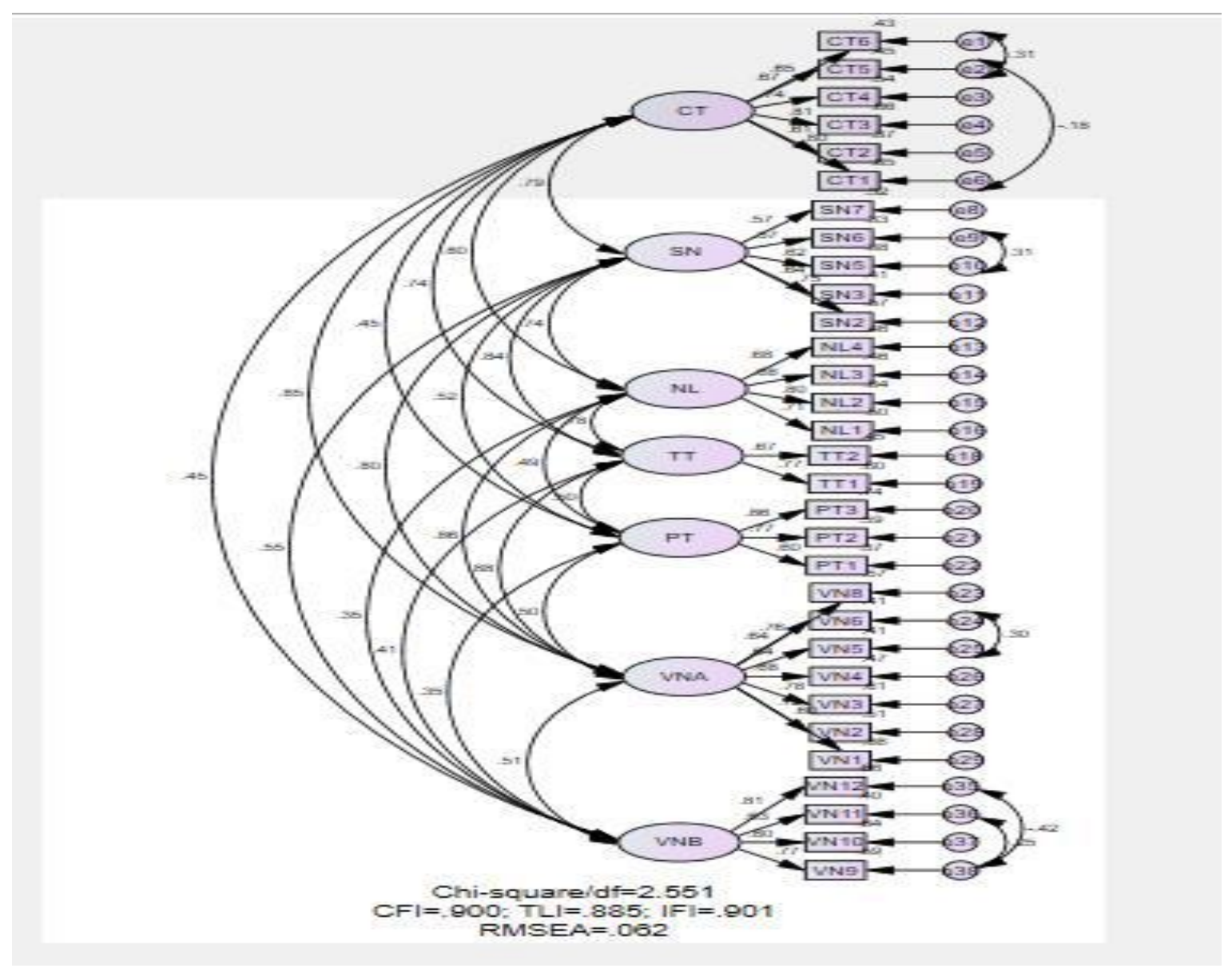

Figure 2: CFA analysis for Vietnam Destination personality

\section{Analysis relationship between Vietnam destination personality and revisit intention}

The result analysis with SEM method shows that the research model achieved overall fit with actual data: Chi-square/df $=2,352$ is smaller $3, \mathrm{CFI}=0,886$, IFI $=0,878$; TLI $=0,886$ are larger than 0.85 and RMSEA $=0,058$ is smaller than 0,08. The result also showed the hypothesis was supported (pvalue $<0.05)$. 
Table 3: Relationship between Vietnam destination personality and revisit intention

\begin{tabular}{|cc|c|c|c|c|}
\hline \multicolumn{2}{|c|}{ Relationship } & Std. Beta & SE & $\begin{array}{c}\text { Critical } \\
\text { ratio }\end{array}$ & p-value \\
\hline DP & $\rightarrow \begin{array}{l}\text { Revisi } \\
\text { intention }\end{array}$ & 0.668 & 0.177 & 5.679 & 0.000 \\
\hline
\end{tabular}

\section{Conclusions}

\section{Implications}

From a theoretical standpoint, the study indicates that tourists do attribute personality characteristics to tourism destinations. This is in line with previous research on destination personality. The six dimensions of destination personality emerged for Vietnam in this study.

\section{Limitations and future research}

The first and the most significant limitation of this study is the lack of random sampling. The data were collected via convenience sampling method. Therefore, the sample did not reflect the entire population of visitors to Vietnam from which the respondents were chosen.

Second, the findings of this study are specific to two tourism destinations (Hanoi and Quangning) and cannot be generalized to other tourism destinations and the sample just focused on English speaking visitors. Therefore, a future research replicating this study with a larger sample size, applying the random sampling method, and for other destinations will increase our understanding of this important research area.

Third, the present study focused on the visitors to Hanoi and Quangning, and the results are limited to the time period of data collection. Thus, for more generalizable results, it is advisable that the sample is surveyed throughout the whole year to prevent any possible seasonal bias. Future research could fill this important gap in the tourism literature by developing a valid, reliable, and generalizable destination personality scale.

\section{Appendix}

Supplementary data associated with this article can be found in the online version, at https://docs.google.com/forms/d/10f--YvruNPN7RFQzYwgt-

4B1OIUemE8rlGfCPoaGnqU/viewanalytics

\section{References}

Aaker, D. A. (1996), Building Strong Brand, The Free Press, New York

Aaker, J. L. (1997), “Dimensions of brand personality”, Journal of Marketing Research, 34, pp. 347

Aaker, J.L. (1995), Brand Personality: Conceptualization, measurement and underlying psychological mechanism, Stanford 
Ajzen, I. (1991). "The Theory of Planned Behavior" Organizational Behavior and Human Decision Processes 50: 179-211.

C. Chen and D. Tsai, (2007), "How destination image and evaluative factors affect behavioral intentions," Tourism Management, vol. 28, no. 4, pp. 1115-1122.

Cai, L. A. (2002), "Cooperative branding for rural destinations", Annals of Tourism Research, 29, pp. $720-742$

Chen, C. F. \& Phou, S. (2013), "A closer look at destination: Image, personality, relationship and loyalty", Tourism Management, 36, pp. 269-278

Chen, C.F., and D.C. Tsai (2007), "How Destination Image and Evaluative Factors Affect Behavioral Intentions?" Tourism Management 28 (4): 1115-22.

Crompton, J. L. (1979), "An assessment of the image of Mexico as a vacation destination and the influence of geographical location upon that image", Journal of Travel Research, 17, pp. 18-23

Crosby, L. A., Evans, R. A. \& Cowles, D. (1990), Relationship Quality in Services Selling: An Interpersonal Influence Perspective, Journal Of Marketing, 54(3), 68-81

Ekinci, Y. \& Hosany, S. (2006), "Destination personality: An application of brand personality to tourism destinations", Journal of Travel Research, 45, pp. 127-139

Ekinci, Y. \& Hosany, S. (2006), "Destination personality: An application of brand personality to tourism destinations", Journal of Travel Research, 45, pp. 127-139

Ekinci, Y., Sirakaya-Turk, E., \& Baloglu, S. (2007), "Host image and destination personality”,Tourism Analysis, 12, pp. 433-446

Fournier, S. (1998), "Consumers and their brands: Developing relationship theory in consumer research", Journal of Consumer Research, 24, pp. 343-373

Freling, T. H., \& Forbes, L. P. (2005), “An emprical analysis of the brand personality effect”, Journal of Product \& Brand Management, 14 (1), pp. 404-413.

Gitelson, R. J., \& Crompton, J. L. (1984), Insights into the repeat vacation phenomenon. Annals of Tourism Research, 11, 199-217.

Grayson, J. L., \& Alvarez, H. K. $\quad$ (2008), School climate factors relating to teacher burnout: A mediator model, Teaching and Teacher Education, 24(5), 1349-1363

Hankinson, G. (2004), "Relational network brands: Towards a conceptual model of place brands", Journal of Vacation Marketing, 10, pp. 109-121

Harris.R.J, (1985), A Primer of Multivariate Statistics, Harcourt Brace Jovanovich, San Diego

Helgeson, J.G., \& Suphellen, M. (2004), "A conceptual and measurement comparison of selfcongruity and brand personality", International Journal of Market Research, 46(2), pp. 205-233.

Heskett, J. L., Jones, T. O., Loveman, G. W., Earl Sasser, W., \& Schlesinger, L. A. (1994), Putting the Service-Profit Chain to Work. Harvard Business Review, 72(2), 164-174

Hosany, S., Ekinci, Y., \& Uysal, M. (2006), "Destination image and destination personality: An application of branding theories to tourism places", Journal of Business Research, 59, pp. 638-642

Howard, J. A., and J. N. Sheth (1969), The Theory of Buyer Behavior. New York: John Wiley \& Sons.

James F. Petrick, J. F. (2004). “Are loyal visitors desired visitors?” Tourism Management, Volume 25, Issue 4, P. 463-470.

Jones, T. O., \& Sasser, W. E. (1995) Why satisfied customers defect? Harvard Business Review, 73(6), 77-88

Jooyeon Ha \& SooCheong (Shawn) Jang (2009), "Perceived justice in service recovery and behavioral intentions: The role of relationship quality", International Journal of Hospitality Management, Vol. 28, pp. 319-327 
Kashyap, R., \& Bojanic, D. (2000), A structural analysis of value, quality and price perception of business and leisure travelers. Journal of Travel Research, 39, pp. 45-51.

Keller, K. L. (1993), "Managing customer-based brand equity”, Journal of Marketing, 57, pp. 1-22

Keller, K. L. (1993), "Managing customer-based brand equity”, Journal of Marketing, 57, pp. 1-22

Kim, S. \& Lehto, X. Y. (2013), "Projected and perceived destination brand personalities: The case of South Korea", Journal of Travel Research, 52, pp. 117-130

Kotler, P., \& Gertner, D. (2004),"'The country as brand, product and beyond: A place marketing and brand management perspective", Destination branding: Creating the unique destination proposition (2nd ed.), Oxford

Kumar, R. \& Mittal, R. K. (2004), Trust and its determinants in Internet banking: A study of private sector banks in India, Decision, 31(1), 76-96

Lau, G. T. \& Lee, S. H. (1999), Consumers" trust in a brand and the link to brand loyalty, Journal of Market Focused Management, 4, 341-370

Lau, L. S. \& McKercher, B. 2004. "Exploration versus consumption: a compariosion of firrsttime and repeat tourists", Journal of Travel Research, 42(3): 279-285

Lee, S.H. (2012), Guidelines for the use of molecular tests for the detection and genotyping of human papilloma virus from clinical specimens, Methods in Molecular Biology, 903, 65-101

Li, F. \& Miniard, P. (2006), On the potential for advertising to facilitate trust in the advertised brand, Journal of Advertising, 35(4), 101-112

Li, F., Zhou, N., Kashyap, R. \& Yang, Z. (2008), Brand trust as a second-order factor: an alternative measurement model, International Journal of Market Research, 50(6), 817-839

Li, X., \& Kaplanidou, K. (2013), "The impact of the 2008 Beijing Olympic Games on China's destination brand: A U. S. -based examination”, Journal of Hospitality \& Tourism Research, 37, pp. 237-261

M. Kozak, (2001 ) "Repeaters" behavior at two distinct destinations," Annals of Tourism Research, vol. 28 , no. 3, pp. 784-807.

Phau, I., \& Lau, K.C. (2000). "Conceptualising brand personality: A review and research propositions. Journal of Targeting", Measurement and Analysis for Marketing, 9(1), 52-69.

Sirgy, M. J. (1982), "Self-concept in consumer behavior: A critical review", Journal of Consumer Research, 9, pp.287-300

Sirgy, M. J. (1982), "Self-concept in consumer behavior: A critical review", Journal of Consumer Research, 9, pp. 287-300

Soyoung Kim, Yuri Lee, Yoo-Kyoung Seock, Yunjin Cho (2009), “Tourists' attitudes towards textiles and apparel-related cultural products: A cross-cultural marketing study" Tourism Management, Vol.30, Issue 5, pp. 724-732

Stokburger-Sauer, N. E. (2011), "The relevance of visitors' nation brand embeddedness and personality congruence for nation brand identification, visit intentions and advocacy", Tourism Management, 32, pp. 1282-1289

Supphellen, M., \& Gronhaug, K. (2003), "Building foreign brand personalities in Russia: The moderating effect of consumer ethnocentrism", International Journal of Advertising, 22, pp. 203-226.

Swan, J. E. (1981), "Disconfirmation of Expectations and Satisfaction with a Retail Service" Journal of Retailing 57 (3): 49-66. 